Published 4 February 2013 in the Journal of Aesthetics and Art Criticism, 71, no. 1, pages 81-90:

https://onlinelibrary.wiley.com/doi/abs/10.1111/j.1540-6245.2012.01544.x

This document contains the post-print version.

NINA PENNER

\title{
Opera Singing and Fictional Truth
}

JOSÉ

Tais-toi! Je t'avais dit de ne pas me parler!

\section{CARMEN}

Je ne te parle pas,

je chante pour moi-même!1

Is Carmen singing? Does she proclaim that which many opera scholars and philosophers are at pains to deny, namely, that opera characters live in a world filled with music and, appropriately, communicate through song? According to Kendall Walton, this question falls under the category of "silly questions," questions for which, as Gregory Currie elaborates, "we ought not to seek an internal explanation when to do so would require us to elaborate improbable scenarios that distract us from the work's real qualities and purpose, and where there is some evident external explanation."2 Both Walton and Currie solve this so-called silly question by admitting a breakdown of representational correspondence between the medium of the performers' utterances and that of the characters. 3 The former is linguistic as well as musical; the latter, solely linguistic. This "solution" accords with the most influential contribution to the study of operatic narratives, Carolyn Abbate's Unsung Voices, in which she presents what I will henceforth refer to as her unheard music thesis: the majority of an opera's music is not part of the ontology of its fictional world. Music is used as a medium to represent nonmusical communicative and expressive acts.4 
I wish to reopen the case of opera singing. Certainly the proposition that denizens of opera's fictional worlds communicate through song requires us to imagine a scenario utterly divorced from our workaday reality. And there is an external explanation for this phenomenon: an opera's authors made this artistic choice because they decided to write an opera and not a play. But does the entertainment of this imagining "distract us from the work's real qualities and purpose"? I argue that it does not.

This article concerns the ontological status and authorship of the music in opera, refining and expanding the work of Edward T. Cone and Peter Kivy.5 Their proposal that opera characters live in a world fundamentally different from ours, a marvelous place where one's every thought and deed passes to music - and where song rather than speech is the normative mode of communication and expression-has not received the attention it deserves in opera studies.6 My extension of Cone and Kivy's work offers a more comprehensive examination of the orchestral music, and addresses several neglected phenomena that are important to the study of modern opera.

\section{THEORIZING OPERA “TALK”}

Cone presented the first theory of the nature of operatic utterance in his Ernest Bloch lectures of 1972.7 He proposed that an opera's music is part of the ontology of its fictional world, but the opera's characters are not always conscious of all of it. They are conscious only of music that they explicitly acknowledge as such. Thus, there are two distinct categories of song: "realistic" songs, such as Cherubino's "Voi che sapete," which is identified as an instance of music-making in the fictional world of Le nozze di Figaro, and "operatic" songs like Cherubino's other aria "Non so più," which is not so identified.8 This distinction is also central to Abbate's theory, but she renames the categories "phenomenal" and "noumenal." Cone views the operatic or noumenal music as representing the "composer's voice," or, to be more precise, the voice of the implied composer.9

Abbate diverges from Cone in her contention that the noumenal music is not part of the ontology of the opera's fictional world.10 This has the serious and undesirable consequence of making it impossible for opera characters to have any form of epistemic access to, or causal powers over, the majority of the music they make. Her theory would seem to bolster the storytelling role of external agents, namely, the work's author(s), but Abbate scrupulously avoids the mention of authors, real or implied. Who is the source of this music? Her answer is alarmingly vague: “to Cone's monologic and controlling 'composer's voice,' I prefer an aural vision of music animated by multiple decentered voices localized in several invisible bodies." 11 In her discussion of Wagner's leitmotivic foreshadowing in Die Walküre, she invokes a radically effaced, implicit narrator to explain the appearance of the Siegfried motive, which foretells 
that Siegfried will rescue Brünnhilde - a fact known to none of the characters since Siegfried has yet to be born.12 It is outside the scope of this article to discuss the coherence and usefulness of the concept of the operatic narrator. I simply state my commitment to ontological parsimony, which demands that there be some reason why one should posit the existence of such entities. It is entirely feasible to attribute the instances of external commentary of which Abbate speaks to Richard Wagner, since Die Walküre is a rare example of a single-authored opera, and one in which the storytelling "voice" is unmistakably Wagner's own.

Cone returned to these operatic-metaphysical debates fifteen years later, putting forth a radically different theory of the nature of operatic utterance in "The World of Opera and Its Inhabitants." This world, he proposed, is filled with music and singing is the normative mode of communication and expression. Characters are not only singers but also composers. They are the authors of the music they sing, as well as its accompaniment, but they do not hear what we hear emitting from the orchestra pit. They "hear" the orchestra that resides in each of their minds. 13

Kivy is possibly the only scholar to publicly acknowledge the merits of Cone's second proposal. He further refined Cone's theory by identifying several problems with his argument and proposing solutions to them. Most pertinent to my argument is his reassertion of the importance of Cone's original distinction between "realistic" and "operatic" singing and his rejection of Cone's internally imagined accompaniment thesis, because it prevents characters from having epistemic access to the accompaniments "authored" by their interlocutors.14 Yet, Kivy's confinement of the role of the orchestral music to just those functions it shares with the vocal music - expressing qualities of the cognitive, affective, and psychological states of characters, as well as gesture and bodily movement—leads him to the conclusion that it always has a fictional author.15 As I will demonstrate, a more comprehensive examination of the narrative functions of the orchestral music suggests that character-authorship is the exception, not the norm.

\section{IMAGININGS ABOUT MUSIC AT THE OPERA}

Kivy is concerned with answering the question: "How are operatic characters "saying'?"16 Since I aim to account for all of an opera's music, not merely that which constitutes the utterances of fictional characters, my question is more general: what is fictionally true about the ontological status and authorship of the music in opera?

Fictional truths are facts about story content. Explicit fictional truths-for example, it is true in the fiction of Le nozze di Figaro that Cherubino is a lovesick teenage boy-are generally uncontroversial. The contentious cases are implicitly generated fictional truths, such as those with which I am concerned. 
There have been many attempts to posit the existence of a priori principles governing the generation of fictional truths, such as the reality principle and the mutual belief principle. The ease with which these principles have been refuted time and again in the philosophical literature raises considerable doubt about whether the mechanics of fictional truth generation are explicable through a priori principles of any sort.17 But that does not mean that the rationalization processes we undergo in our determination of a work's fictional content are entirely unsystematic. My conception of fictional truth follows that proposed by Paisley Livingston: fictional truths are those propositions that are appropriate to imagine, given a particular interpretive purpose. If one's aim is to appreciate an opera as a work of art created by real people working in a particular historical-artistic context, fictional truths are jointly determined by features of the work itself, and the effective, communicative intentions of the work's real author(s).18

Accepting that authorial intentions are pertinent to interpretation does not entail regarding authors as infallible, nor does it devalue the role of the interpreter. The moderate intentionalist position I support holds that the intentions of a work's author(s) figure in the determination of the work's fictional content and meaning, but are neither necessary nor sufficient to determine either. An author's intention to endow her work with a given property does not entail that it actually possesses that property, since authors are not always successful in realizing their intentions. Conversely, the fact that a work possesses a given property does not necessarily mean that the author intended to impart that property to her work.19

I propose the following as default, trans-work, opera-specific fictional truths. Fictional content must be determined on a case-by-case basis. Thus, I stress that all are defeasible, if contradicted by other, more salient fictional truths generated in individual operas. These are merely striking commonalities that can be observed among the majority of works of this genre, but do not constitute necessary or sufficient conditions for genre membership.

First, an opera's music is an inextricable part of the ontology of its fictional world. Operatic worlds possess radically different ontologies than that of our world, but this is hardly a unique situation. As George Wilson observes with regard to cinema, spectators are sometimes required to adopt "a certain epistemic distance from their usual habits of perception and common-sense beliefs" in their determination of a film's fictional content.20 With opera, this situation is simply the norm rather than the exception.

Second, song is the normative mode of communication and expression in the fictional world. There are some notable exceptions, such as characters who must make do with words alone; for example, the Pasha Selim in Die Entführung aus dem Serail. And some extraordinary characters express themselves entirely through gesture or dance, such the deaf and mute Fenella in La muette de Portici and Tadzio in Death in Venice, who is not handicapped, but nevertheless does not sing. 
Third, the characters are the authors of their own sung utterances in the fictional world. If an opera's music is not part of the ontology of its fictional world, it is impossible to attribute its authorship to fictional characters. Cone has already mentioned this problem, commenting that it is unsatisfying to imagine that a significant portion of a character's utterance is "proceeding in no way from the personality and motivations of the character himself." 21 I contend that it is not merely unsatisfying but incorrect to attribute the authorship of a character's explicitly made utterance to anyone but that character. This is true even in the case of a character's utterance possessing properties that the character cannot have intended to impart. A familiar case is that of an utterance for which the musical and linguistic portions contradict one another and where it is not reasonable to suppose that the character intended this disjuncture (as one might do for comic or ironic effect). In this case, one must attribute the conflict to the work's author(s), who might use it to characterize the character in question as duplicitous or delusional, for example. The character is still the fictional author of his utterance, despite the fact that some of its salient features were not intended by the character.

Fourth, although it is true that all performances of songs are performances of art, it is not always fictionally true that instances of singing are artistic performances. Accepting that the majority of opera characters express themselves through song does not entail regarding all such performances as artistic performances in the fictional world of an opera. Even though I reject Abbate's terminology (phenomenal and noumenal song), since it makes a dubious ontological distinction between these two categories of song, I believe in making a distinction between musical performances that are artistic performances in the world of the fiction and musical performances that do not constitute performances of works of art. Explicit features of many operatic works - along with the information that can be gleaned from these features about authorial intentions - confirm that this distinction is fundamental to the appreciation of opera. First, one can observe a difference in the manner in which characters react to artistic musical performances, for example, by evaluating the aesthetic merits of these performances, as do the characters in Die Meistersinger during the song contest. Second, there is almost always a marked shift in musical style. If the opera is set in the past, a composer might adopt a quasi-antique style that draws on traditional song forms, as Britten does in the Ballad in Owen Wingrave. Or if it is an Orientalist opera, the composer may write in an "exotic" style, as in Osmin's "Turkish" Lied, "Wer ein Liebchen hat gefunden" in Die Entführung. There are some works in which the distinction between artistic and nonartistic musical performances is more nebulous. The utterances of "Oriental" characters, such as Osmin and Carmen, often resist classification, because it was conventional to represent such characters as having an innate propensity toward artistic expression through music or dance. Cone eagerly exploits Carmen's transgressiveness in this regard as part of his attempt to dissolve the distinction between "realistic" and 
"operatic" singing, but he errs in extrapolating the ambiguities endemic to a single opera to the genre as a whole.22 Rather, the fact that the utterances of Carmen and Escamillo routinely defy classification, whereas those of José and Micaëla do not (they never make artistic performances), indicates something fundamental about these characters and thus confirms the importance of the distinction between artistic and nonartistic musical performances.

Fifth, the orchestral music is also part of the ontology of the fictional world, even if it does not have a fictional author. Kivy's proposal that the orchestral music can always be attributed to a fictional author is inadequate to explain the provenance of accompaniments to ensembles, orchestral music not accompanying characters' utterances, and leitmotivic foreshadowing. The proposition that characters author their own accompaniments suggests that the normative practice in composing ensembles would be for the accompaniment to change drastically with each change of singer. A cursory examination of ensembles from any point in opera history will confirm that this is not the case. In an attempt to explain this observation in a manner that accords with Kivy's proposal, one could argue that the accompaniment expresses commonalities of the characters' states of being. A particularly vivid illustration is the "ensemble of stupefaction," the slow section in many internal finales in late eighteenth- and early nineteenth-century opera buffas, for example, in the Act I Finale of Il barbiere di Siviglia at "Fredda ed immobile come una statua." One of the genre's characteristic plot twists has just occurred. The characters are stunned and perplexed, so much so that their frenetic musical and stage business has come to a halt. They have vastly different personalities, ambitions, and thus responses to the most recent turn of events, but they are united in at least one quality of their state of being at this moment: stupefaction. Who is responsible for determining that the most salient commonality among the characters is stupefaction, and how did the music come to express this quality? I will reserve my answer to these questions until I have examined each of the aforementioned cases.

The use of music to depict setting or create mood is beyond the purview of Kivy's proposal. Cone, in his discussion of the Sea Interludes in Peter Grimes, proposes that this music is a product of the imagination of the "collective musical consciousness of those with whom Britten populated his village." 23 In other words, it is collectively authored by the fictional characters. I support Cone's intriguing suggestion that the manner in which the vicissitudes of the North Sea are transmuted into music is in a counterfactual relationship with how the inhabitants of the Borough perceive these sounds. I disagree with Cone's explanation of this phenomenon, however, since it raises the question of how this miraculous state of affairs comes to pass.

Through the recurrence and development of musical thematic material, composers can foreshadow future developments in the narratives of their operas that no fictional agent could know, anticipating, for 
example, that Siegfried will brave the magic fire to free Brünnhilde. The recourse to an entity external to the fictional world is unavoidable in this case, as well as in those cases cited above, since fictional agents lack the necessary causal powers over the orchestral music. These examples have no fictional author, but this should not trouble us unduly. For the inhabitants of the Borough, the music of the Sea Interludes is merely there, like the weather it represents. Real-life spectators of Peter Grimes, on the other hand, know that Benjamin Britten composed it.

A staunch supporter of the fictional authorship of the orchestral music could classify the troubling questions I raise under the category of silly questions and declare the mechanism responsible for these phenomena fictionally indeterminate. Sometimes such an argument is our only opinion in making sense of a given fiction, but I caution against its overuse. There must be a good and sufficient reason why we should imagine propositions whose implications generate silly questions. In the case of opera singing, there is one: communicating through song is what opera characters appear to do, and accepting this aids in our understanding and appreciation of the narratives their musical deeds create. We lack a good and sufficient reason to suppose that opera characters author music for which they do not appear to be responsible and in fact lack the requisite knowledge and causal power to determine all of its salient features. It is more appropriate to assume that the orchestral music does not have a fictional author, except in cases where one is identified, explicitly or implicitly. For example, in a production of Le nozze di Figaro that involves the singer performing the role of Susanna appearing to play a guitar-like instrument in "Voi che sapete," it is fictionally true that Susanna is the source of the song's accompaniment, even though members of the orchestra are the actual source of this music, generating a sound quantitatively and qualitatively different than that which would be emitted from the instrument in the singer's hands. A potential implicit case is Abbate's argument that Wotan is the author of the orchestral music that corroborates the story he tells to Brünnhilde in Die Walküre, Act II. It is possible that Wagner intended audiences to attribute the orchestral music in this manner, even though doing so raises the question of how Wotan possesses this magical power.24

Sixth, hearing does not necessarily entail understanding in opera's fictional worlds. Not all spectators attending Die Walküre recognize the appearance of the Siegfried motive at the opera's conclusion and realize what it portends. Similarly, there is no logical problem generated by allowing the characters to hear this music. Abbate maps characters' perceptual-interpretive abilities onto the following binary: nothearing (and, thus, not understanding) and hearing (leading to complete understanding). These states are exemplified in her juxtaposition of Gutrune and Brünnhilde.25 I propose that all opera characters with normally functioning aural-perceptual abilities hear the music. Gutrune merely possesses less musicalinterpretive competence than Brünnhilde.26 I conceive of musical-interpretive competence as a spectrum 
ranging from willful obliviousness - analogous to shoppers tuning out the muzak played in grocery stores - to sophisticated critical-listening skills.

Many characters lack sufficient skill in musical interpretation, even though they have perfectly adequate hearing. This flaw is particularly dire for denizens of operatic worlds, as the case of Sempronio in Lo speziale attests. In his adaptation of Goldoni's La finta ammalata, Haydn restored hearing to the deaf character Agapito when he transformed him into the opera character Sempronio. Rebecca Green argues that although Sempronio is not deaf in the literal sense, he is "deaf" to the meanings of the music.27 In the Act II Finale, Sempronio appears to get his heart's desire when his ward Grilletta agrees to marry him. What he does not know is that the notaries are none other than Grilletta's lover Mengone and another hopeful suitor Volpino, who each attempt to write themselves into the marriage document. Mengone and Volpino repeat the ends of Sempronio's statements to assure him that they are taking faithful dictation, but due to pronominal ambiguity, the linguistic portions of their utterances can neither confirm nor deny this. The music does confirm that the suitors are not following Sempronio's directions by failing to confirm the initial key established by Sempronio and modulating to others of Mengone's and Volpino's choosing.28 The humor of this scene relies on the fact that all of the characters hear the music, including Sempronio. However, Sempronio is the only one who lacks the musical-interpretive sophistication to recognize the warning signs that a plot against him is afoot.

\section{OPERA CHARACTERS AND EPISTEMIC ACCESS}

Abbate's unheard music thesis is predicated upon the assumption that it is possible to separate the linguistic and musical components of characters' sung utterances and accord them different ontological statuses. The problem is that song is the fusion of words and music. An adequate account of the meaning and illocutionary force of such an utterance can arise only from the consideration of both constituent components. This is a truism in opera studies. What appears to be more controversial is my claim that it is equally true for opera characters. Denying characters epistemic access to the musical portion of the utterances they and others make hinders their ability to understand these utterances and thus leaves the interpreter unable to explain how they gain the knowledge that causes them to act in the manner that they do.

When knowledgeable spectators watch an opera, they reach many important conclusions about the opera's characters based on the kinds of musical-linguistic utterances each makes. Is it not appropriate to imagine that the characters undergo a similar process of sizing up each other, which informs their decisions about who is friend, foe, or lover? It is a convention of opera buffa that seria sopranos and buffa 
baritones or basses do not fall in love, since their voice types were considered incompatible. The conspicuous exception is Cosi fan tutte, in which the initial couplings of Fiordiligi and Guglielmo (seria soprano and buffa baritone) and Dorabella and Ferrando (buffa mezzo and seria tenor) go against convention. But there is much, in both the music and text of Così, to suggest that the lovers do not know each other, or their own hearts, as well as they profess. After the men assume fake identities, the women make their choices based solely on their perception of the relative attractiveness of the two suitors. Lo and behold, the characters re-sort themselves into like-voiced pairs.

The sound of the men's voices is not the only determining factor in the women's decisions, one could argue. Even in an opera, sound is only infrequently the sole means by which opera characters gain epistemic access to their world. The fourth act of Le nozze di Figaro comes close to this scenario, since it takes place in an unilluminated garden at night, and Susanna and the Countess are disguised as each other. The success with which characters form veridical beliefs about each other's identities turns on their abilities not merely to hear but to listen critically to what they are hearing. The rationalization processes characters make explicit to us bear this out. The libretto abounds with such statements as "questi è il Conte, alle voce il conosco" [that is the count; I recognize his voice]. The key to the success of the women's ruse is their donning of musical disguises as well. They easily fool the Count and Cherubino, but when Susanna converses with Figaro, she forgets to alter her voice, and he hears through her disguise.29 In retribution for her keeping her scheme a secret and causing him undue distress, he proceeds to declare his love, while still pretending he believes her to be the Countess. She drops the act and exacts her revenge with her fists until he consoles her: "Pace, pace, mio dolce tesoro: / Io conobbi la voce che adoro" [peace, my darling / I recognized the voice that I love]. Incredulous Susanna asks Figaro if it was really her voice that gave her away, and he confirms it. Evidently Mozart and Da Ponte deemed this point important enough to warrant reiteration.

The abundance of impersonation plots in eighteenth-century opera buffa make it a wellspring of examples of the importance of hearing to the well-informed opera character, but my contention extends beyond this repertory. Abbate herself comments on the "epistemological hierarchy" evident in the Siegmund-Sieglinde recognition scene in Die Walküre, "in which sound conveys a great truth, while image can be insufficient or misleading." As she observes, "Siegmund and Sieglinde principally discover each other's identity not through recognising a face, but by sensing an unmistakable quality of voice; as Sieglinde says, 'ach still, laß mich der Stimme lauschen; mich dünkt's, ihren Klang hörte ich als Kind. Doch nein, ich hörte sie neulich, als meiner Stimme Schall mir widerhallte im Wald." 30 [Hush, let me listen to the voice. Methinks I heard its sound as a child. But no, I heard it recently when the sound of my voice echoed back to me in the forest.] 
The type of musical discourse characters employ is equally important to the plots of modern operas like Moses und Aron. Moses communicates through Sprechstimme and the difficult, modernist musical discourse for which Schoenberg was notorious, whereas Aron sings lyrically, making the most of his Heldentenor voice. It is Aron's exquisite musical utterances that endear him to the people and make his message more attractive than his brother's. One could regard the music as a symbol of the relative persuasiveness with which the characters articulate themselves in words, but given that the story of Moses und Aron is a metaphor for the condition of the modern composer, and Moses Schoenberg's thinly veiled self-portrait, I find it more rewarding to regard the characters as literally communicating through music and being judged on the relative merits of their music.

\section{LISTENING TO THE VOICES OF OPERA'S AUTHORS}

Poststructuralist narrative theory has given real authors short shrift, focusing primarily on fictional narrators. But the acknowledgment of the voices of an opera's authors is crucial, I contend, particularly to the study of modern opera, since external perspectives are often salient. Interpreters need recourse to the beliefs, intentions, and actions of the real Benjamin Britten to understand the significance of many of the features of his operas. All are highly personal meditations on themes and issues dear to him, none more so than his and Myfanwy Piper's adaptation of Thomas Mann's Der Tod in Venedig. In telling his story, Mann projects a persona that increasingly distances himself from Aschenbach by offering highly judgmental commentary on the character's actions. By the end, he reports the protagonist's death with clinical disinterestedness: "Some minutes passed before anyone hastened to the aid of the elderly man sitting there collapsed in his chair. They bore him to his room. And before nightfall a shocked and respectful world received the news of his decease." 31 Britten's music presents a remarkably different point of view on Aschenbach.32 It is not merely uncritical, but, particularly at the moment of Aschenbach's death, actively beckons the spectator to sympathize with his fate. Britten represents Aschenbach's Liebestod as an unabashed glorification of the union of the lover and the beloved, which could only be achieved in death and enacted through music. After Aschenbach's body slumps in his chair, his musicpreviously sung to the words "when thought becomes feeling, feeling thought" in Act I, now played by the strings with supporting winds - rises up with Tadzio's gamelan-inspired theme in a glorious apotheosis, finally uniting on a high A, performed by a single representative of each of these instrument groups. The opera's deeply sympathetic point of view of Aschenbach and its romanticization of his death were undoubtedly Britten's doing and express something of his experience, both as an aging artist in rapidly deteriorating health who was concerned that his creativity was on the decline and as a gay man 
drawn to prepubescent boys.33 While there is incentive to posit an implied or, as Dorrit Cohn suggests, "second" author in Mann's Der Tod in Venedig, there is no such incentive in the case of Britten's opera.34 One would merely endow this entity with precisely the same point of view as the actual composer, and doing so would only obscure what Britten had to say with his adaptation.

Listening to authorial voices can also yield insights into the creative process. Operas are almost always multi-authored works, often produced in a collaborative manner. Sometimes this enterprise is fraught with conflict and discontent, in many instances resulting from an undemocratic power structure that accords the composer the last word, so to speak. Britten frequently exploited this situation to provide critical commentary on the work of his librettists by disregarding or actively subverting their intentions. Vere's final monologue in Billy Budd is exemplary in this regard. In the opera, unlike Melville's novel, Vere lives to be an old man, an idea that originated with E. M. Forster, the primary librettist. The opera is framed by scenes of Vere reminiscing, and it is clear that Forster intended the final monologue to provide not only closure but a hopeful, redemptive ending. 35 Vere answers the questions he poses at the opera's outset in its conclusion and he declares that his "mind can go back in peace." Britten's music undercuts these pronouncements by failing to provide either consonant harmonic support to Vere's vocal line or tonal closure that would accord with the closure afforded by Forster's text.36 For example, when Vere declares "I'm content," the critical word falls on an A7 chord, which is foreign to the ostensible key of this section, B-flat. The orchestra's boisterous re-affirmation of B-flat that occurs subsequently is jarring and, although the orchestra does not waver from this key, Vere is unable to conform to it. Instead, his vocal line exhibits the same destabilizing influence of B minor that characterized the Prologue.37 Although recapitulating opening material at the end of a musical work often brings about a sense of closure, it does not in this case because of the tortured nature of this material. Rather, it suggests that Vere is caught in a vicious cycle of reliving the past and attempting to find peace in the acceptance of Billy's forgiveness. Through his music, Britten not only conveys his opinions about Vere, but in his pointed denial of the kind of ending Forster intended, he also conveys his attitudes toward Forster's characterization of Vere, highlighting the divergent views the collaborators had toward the story they were ostensibly telling together.

\section{FICTIONAL TRUTHS AND OPERATIC CONVENTIONS}

For my musicological colleagues, I hope to have shown some of the merits of the view of operatic metaphysics I propose, but I realize that philosophically inclined readers are still waiting for me to 
elucidate what makes the components of my heard music thesis fictionally true. This final section addresses this concern.

According to a moderate intentionalist account of fictional truth, one must take into consideration the features of the work itself and the effective, communicative intentions of its author(s). The proposition that opera characters communicate through song and hear the music they and their cohorts make is directly warranted by explicit features of operatic works. Performers express themselves through music, either by directly producing it or by reacting to it through speech, gestures, or dance. They provide ample proof that they hear not only the music they make, but also the music of their fellow performers, including the orchestra. Appreciating an opera as a narrative involves entertaining certain prescribed imaginings about its fictional world. Most fundamentally, the spectator must imagine that the performers he sees represent characters in the fictional world. Why should the spectator doubt that the characters are engaged in the same actions and possess the same perceptual abilities as the performers who play them? I propose that there is no reason to doubt the proposition that a given opera's characters communicate through song and hear the music they and others make unless (1) a given opera's author(s) effectively signal that this proposition is not fictionally true (that is, it conflicts with other, more salient fictional truths) or (2) there is a good and sufficient reason to believe that the opera was produced in accordance with a convention that prescribes that this proposition does not apply.

I cannot think of a single example of an opera's authors signaling within their work that the heard music thesis is not applicable. However, it does not follow that this would be impossible. In fact, one example of a moment in a particular performance that contradicts my thesis is Louis Erlo's and Alain Maratrat's staging of Les brigands for the Opéra de Lyon, 1989.38 In Act III scene 3, Le Caissier is anxious about the arrival of the Spanish, from whom he has embezzled a fortune. Henri Meilhac's and Ludovic Halévy's libretto explicitly states that the sound of castanets is to be heard while the character talks to himself, prompting his exclamation that the Spanish have arrived.39 Erlo and Maratrat disregard this direction. The onstage orchestra that provides the musical cue does not supply the requisite sound of castanets. Le Caissier's exclamation that he hears castanets appears to be completely sincere; there is no reason for him to lie, since he is talking to himself. He believes he hears castanets, perhaps because it accords with his expectation of the impending arrival of the Spanish and beliefs about the identities of Falsacappa, Fiorella, and their band of brigands. Erlo's and Maratrat's staging reminds the audience of the faultiness of these beliefs. It is true in the fiction of their performance of Les brigands that Le Caissier hears - or, rather, believes he is hearing - different music than we do; thus, this performance constitutes an example of (1), localized to Le Caissier at this particular moment. However, Le Caissier's aural 
hallucination is not a fictional truth of the work as conceived by its creators, as this performance deviates from the directions in the work's libretto.

The proposition that the majority of an opera's music is literally unheard in its fictional world is not supported by explicit features of operatic works - except in exceptional cases, such as the performance just described. Thus, proponents of this position rely upon the existence of the convention cited in (2). This is precisely the claim Abbate makes when she states that her unheard music thesis constitutes a "basic perceptual code in hearing and viewing opera." 40 When asserting a claim about the existence of a convention, the burden of proof falls to the asserter to advocate for its existence and influence over the actions of opera makers and opera audiences. No such argument has been advanced by Abbate or anyone else, to my knowledge, for the simple reason that the unheard music thesis does not describe an operatic convention.

The definition of convention I employ is based on Livingston's adaptation of David Lewis's gametheoretical definition for use in literary criticism.41 Conventions describe a regularity of behavior within a given group of people (in our case, authors and audiences of opera) that is a solution to a recurrent "coordination problem," a situation in which the people in this group possess a common goal, where the attainment of this goal depends on the actions of the other people in the group. For authors, the "goal" of producing a work of art is to have it be appreciated by audiences in some preferred manner; for audiences, the goal is to appreciate the work in the author's preferred manner. It should be clear that the foregoing situation does not describe all situations of opera production and reception, since the condition that the goals of all agents coincide is not always satisfied. As Lewis demonstrates, "conventions need not originate by convention - that is, by agreement"; what makes a solution conventional is "the way it persists." 42 A convention is not merely any regularity one can observe amongst works in a given corpus. Livingston explains, "not only must everyone conform to the regularity, but everyone must believe that the others conform to it, and this belief is what gives everyone a good and decisive reason to conform to it." 43 Thus, in addition to identifying a recurrent feature, one must demonstrate that the appropriate "beliefs, preferences, and expectations" of authors and audiences contributed to the authors endowing their works with this recurrent feature.44

Abbate has not demonstrated that the right sorts of beliefs, expectations, and preferences influenceor influenced at any point in history - the production and reception of opera, aiding in the coordination of authors' and audiences' goals to make and appreciate opera in the manner she describes. In refuting Abbate's claims, I am not asserting that the converse, my heard singing thesis, describes an operatic convention. The default fictional truths I enumerated in section II are merely recurrent features observable among the vast majority of operatic works. The very fact that these issues are so hotly contested by opera 
scholars illustrates that my propositions do not meet the stringent demands of conventionality described above. Nevertheless, belief in the heard music thesis leads to a more coherent understanding of operatic metaphysics and allows for the wide range of musical-interpretive competencies displayed by opera characters. Furthermore, recognizing that fictional authorship of the orchestral music is a relatively infrequent phenomenon highlights the storytelling acts of opera makers, the consideration of which is particularly important to the study of modern opera.

Samuel Johnson famously described opera as "an exotick and irrational entertainment." 45 Opera's fictional worlds are certainly exotic, in that they possess extremely nonnaturalistic ontologies and characters with extraordinary means of communication and expression. But opera is only irrational if one refuses to approach it on its own terms. It is high time that those of us in opera studies recognized opera's metaphysical exoticism and stopped attempting to mold our conceptualization of its fictional worlds and their inhabitants to the norms of our comparatively mundane reality.46

\section{NINA PENNER}

Schulich School of Music

McGill University

Montréal, Québec H3A 1E3, Canada

INTERNET: nina.penner@mail.mcgill.ca

1. JOSÉ: "Shut up! I told you not to talk to me!" CARMEN: "I'm not talking to you, / I'm singing for myself!" All translations are my own.

2. Kendall L. Walton, Mimesis as Make-Believe: On the Foundations of the Representational Arts (Harvard University Press, 1990), sec. 4.5; Gregory Currie, Narratives and Narrators: A Philosophy of Stories (Oxford University Press, 2010), p. 59.

3. Walton, Mimesis as Make-Believe, p. 182; Currie, Narratives and Narrators, p. 59.

4. Carolyn Abbate, Unsung Voices: Opera and Musical Narrative in the Nineteenth Century (Princeton University Press, 1991), p. 119.

5. Edward T. Cone, "The World of Opera and Its Inhabitants," in Music: A View from Delft, ed. Robert P. Morgan (University of Chicago Press, 1989), pp. 125-137; Peter Kivy, "Opera Talk: A Philosophical 'Phantasie,", Cambridge Opera Journal 3 (1991): 63-77; Peter Kivy, "Speech, Song, and the Transparency of Medium: A Note on Operatic Metaphysics," The Journal of Aesthetics and Art Criticism 52 (1994): 63-68. 
6. See, for example, David Rosen's dismissive response, "Cone's and Kivy's 'World of Opera," Cambridge Opera Journal 4 (1992): 61-74. Rosen grossly misrepresents Kivy's position, as Kivy retorts in "Composers and 'Composers': A Response to David Rosen," Cambridge Opera Journal 4 (1992): $179-186$.

7. Published in Edward T. Cone, The Composer's Voice (University of California Press, 1974), chap. 2.

8. Cone coins these terms in his later article "The World of Opera and Its Inhabitants," p. 126.

9. Cone does not use the term "implied composer," but the following statement makes it clear that this is the identity to which he refers when he speaks of the "composer's voice": "Note, however, that this means not 'the persona of the composer' but ' $a$ persona of the composer'; for the persona of each composition is uniquely created by and for that composition." The Composer's Voice, p. 18.

10. Abbate's articulation of her position is ambiguous. At first, she appears to be in sympathy with Cone when she proposes that opera characters "suffer from deafness; they do not hear the music that is the ambient fluid of their music-drowned world," but further down in the same paragraph, she states that the music "is not produced by or within the stage-world, but emanates from other loci as secret commentaries for our ears alone." Unsung Voices, p. 119. The latter position is more consistent with her analyses as well as her choice of terminology.

11. Abbate, Unsung Voices, p. 13.

12. Abbate, Unsung Voices, p. 169.

13. Cone, "The World of Opera and Its Inhabitants," pp. 136-137.

14. Kivy, “Opera Talk,” pp. 73-75.

15. Kivy, "Opera Talk," p. 73. Cone, "The World of Opera and Its Inhabitants," p. 138, is more cautious, admitting that there are exceptions, particularly in Wagner's works.

16. Kivy, "Opera Talk," p. 63.

17. For example, Gregory Currie, The Nature of Fiction (Cambridge University Press, 1990), chap. 2; Paisley Livingston, Art and Intention: A Philosophical Study (Oxford: Clarendon Press, 2005), pp. 186200; Walton, Mimesis as Make-Believe, chap. 4.

18. Paisley Livingston, "Characterization and Fictional Truth in Cinema," in Post-Theory: Reconstructing Film Studies, eds. David Bordwell and Noël Carroll (University of Wisconsin Press, 1996), p. 165; Livingston, Art and Intention, pp. 196-198.

19. Livingston, "Characterization and Fictional Truth in Cinema," p. 164.

20. George Wilson, Narration in Light: Studies in Cinematic Point of View (Johns Hopkins University Press, 1986), p. 4. 
21. Cone, The Composer's Voice, p. 31.

22. Cone, “The World of Opera and Its Inhabitants," p. 131.

23. Cone, "The World of Opera and Its Inhabitants," pp. 136-137.

24. Abbate, Unsung Voices, pp. 187-205. It should be noted that Abbate does not claim that her interpretation corresponds with Wagner's intentions.

25. Abbate, Unsung Voices, pp. 219, 223.

26. Richard Taruskin, Oxford History of Western Music, vol. 1 (Oxford University Press, 2010), p. 827 , suggests that what Abbate really means when she says that the noumenal music is "unheard" by the fictional characters is that it is not interpreted. See also his review of Unsung Voices, "She Do the Ring in Different Voices," Cambridge Opera Journal 4 (1992): 187-197, at p. 196, where he refutes Abbate's claim that the noumenal music emanates "from without," and proposes that "characters do not merely hear it; they live it."

27. Rebecca Green, "From Agapito to Sempronio: Deafness and Hearing in the Operatic Theatre," in Goldoni and the Musical Theatre, ed. Domenico Pietropaolo (Ottawa: Legas, 1995), pp. 83-109.

28. Rebecca Green, "From Agapito to Sempronio," pp. 95-96; Caryl Clark, “The Opera Buffa Finales of Joseph Haydn” (Ph.D. diss., Cornell University, 1991), p. 65.

29. The libretto states "si scorda di alterare la voce" [forgetting to alter her voice], which Mozart represented through Susanna's lapse into to the less dignified musical discourse we have come to expect from her.

30. Carolyn Abbate, "Immortal Voices, Mortal Forms," in Analytical Strategies and Musical Interpretation: Essays on Nineteenth- and Twentieth-Century Music, eds. Craig Ayrey and Mark Everist (Cambridge University Press, 1996), p. 293.

31. Thomas Mann, "Death in Venice," in Death in Venice and Seven Other Stories, trans. H. T. Lowe-Porter (New York: Vintage, 1989), p. 73. This is the translation Piper and Britten used.

32. Philip Rupprecht, Britten's Musical Language (Cambridge University Press, 2001), chap. 6, presents a compelling music-theoretical exegesis of Britten's "compassionate" view of Aschenbach.

33. Kimberly F. Canton, Amelia Defalco, Linda Hutcheon, Michael Hutcheon, Katherine R. Larson, and Helmut Reichenbacher, "Death in Venice and Beyond: Benjamin Britten's Late Works," University of Toronto Quarterly (forthcoming, 2012); John Bridcut, Britten's Children (London: Faber, 2006).

34. Dorrit Cohn, The Distinction of Fiction (Johns Hopkins University Press, 1999), chap. 8.

35. Forster's self-proclaimed intentions were to "rescue Vere from Melville," and to "make Billy, rather than Vere, the hero," by Billy offering Vere salvation in the end. Quoted in Philip Brett, "Salvation 
at Sea: Britten's Billy Budd," in Music and Sexuality in Britten: Selected Essays, ed. George E. Haggerty (University of California Press, 2006), pp. 72, 79 footnote 2.

36. My interpretation of this scene accords with that proposed by Arnold Whittall, "'Twisted Relations': Method and Meaning in Britten's Billy Budd," Cambridge Opera Journal 2 (1990): 166-169. Several other noted scholars do not view the music and text as working at cross purposes, however. Brett, "Salvation at Sea," p. 78, characterizes the ending as an expression of "unalloyed optimism." Clifford Hindley, “Love and Salvation in Britten's Billy Budd," Music \& Letters 70 (1989): 363-381, at p. 381, describes it as a "tranquil recollection."

37. Refer to Philip Rupprecht, “Tonal Stratification and Uncertainty in Britten's Music," Journal of Music Theory 40, no. 2 (1996), 311-332, for an analysis of the conflict between the tonal areas of B-flat and B-natural in the Prologue.

38. My knowledge of this production was acquired from viewing the following DVD: Jacques Offenbach, Les brigands, conducted by Claire Gibault, stage direction by Louis Erlo and Alain Maratrat, video direction by Yves André Hubert (Image Entertainment, 2002). I am grateful to Alixandra Haywood for bringing this delightful example to my attention.

39. Théatre de Meilhac et Halévy, vol. 7 (Paris: Calmann-Lévy, 1901), p. 245.

40. Abbate, Unsung Voices, p. 119.

41. Paisley Livingston, "Convention and Literary Explanation," in Rules and Conventions: Literature, Philosophy, Social Theory, ed. Mette Hjort (Johns Hopkins University Press, 1992), pp. 6794; David Lewis, Convention (Harvard University Press, 1969).

42. David Lewis, "Languages and Languages," in Language, Mind, and Knowledge, ed. Keith Gunderson (University of Minnesota Press, 1975), p. 26.

43. Livingston, "Convention and Literary Explanation," p. 71.

44. Livingston, "Convention and Literary Explanation," p. 74.

45. Samuel Johnson, The Lives of the Most Eminent English Poets with Critical Observations on Their Works, vol. 2 (London: C. Bathurst, 1781), p. 449.

46. Heartfelt thanks to Trevor Ponech for asking me the question that brought this article into existence, and to Lloyd Whitesell, whose equally productive disagreements undoubtedly made my arguments stronger. 